\title{
Pengaruh Servicescape Terhadap Kepuasan Konsumen Pada Pt. Pegadaian (Persero) Cabang Bima
}

\author{
RemitaMiranti $^{1)}$, Amirulmukminin ${ }^{2)}$ \\ ${ }^{1,2}$ Prodi Manajemen, STIE BIMA \\ email: ${ }_{2}^{1}$ remitamiranty16stie@gmail.com \\ amirul.stiebima@gmail.com
}

\begin{abstract}
Penelitian asosiatif ini dilakukan untuk melihat ada tidaknya pengaruh servicescape terhadap kepuasan konsumen pada PT. Peagadaian (persero) Cabang Bima. Untuk melihat ada pengaruh atau tidak diambil data menggunakan instrument dengan skala likert. Sebelum isntrumen dibagikan pada responden yang berjumlah 96 orang dari populasi yang tidak diketahui, kuisioner tersebut diuji validitas dan reliabiltas, sehingga diperoleh rata-rata nilai

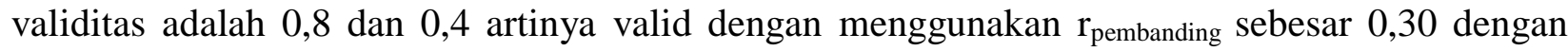
nilai reliabilitas, 0,854 dilihat dari nilai Cronbach's Alpha. Dari hasil analisis yang dilakukan menggunakan SPSS Versi 20, diperoleh bahwa Servicescape secara parsial berpengaruh signifikan terhadap Kepuasan Konsumen pada PT. Pegadaian (persero) Cabang Bima. Hal itu diketahui dari perbandingan nilait ${ }_{\text {hitung }}=6,587>\mathrm{t}_{\text {table }}=1,984$ atau dilihat dari nilai sig $=0,05<\alpha$ $=0.00$.
\end{abstract}

Kata Kunci :Servicescape, Kepuasan Konsumen

\section{PENDAHULUAN}

Pegadaian adalah salah satu lembaga keuangan terbesar di Indonesia yang telah melayani masyarakat sejak 118 tahun yang lalu. Dalam menjaga kelanjutan dari Pegadaian yang secara konsisten mampu menjawab kebutuhan keuangan masyarakat Indonesia, maka Pegadaian harus didukung oleh tim tenaga penjual yang mumpuni.Dengan perkembangan dunia usaha saat ini Pegadaian perlu melakukan strategi pemasaran. Strategi pemasaran merupakan salah satu faktor yang bisa membuat suatu perusahaan bisa sukses menghadapi persaiangan, menciptakan, meraih konsumen baru dan mempertahakan konsumen yang loyal. Kepuasan konsumen dapat diketahui lewat kualitas pelayanan dan juga lewat lingkungan fisik atau dikenal dengan servicescape. Servicescape merupakan konsep layanan yang diberikan oleh perusahaan lewat pemuasan lingkungan fisik konsumen. Maksudnya perusahaan berusaha untuk memberikan kepuasan terhadap pancaindra konsumen mulai dari mata,hidung,telinga,mulut serta tangan.
Hasil observasi diperoleh beberapa kekurangan diantaranya, pendinginan tidak maksimal sehingga pengunjung sering mengeluh kepanasan, tidak tersedianya petugas parkir sehingga pengunjung merasa khawatir kehilangan motor, termasuk juga tenaga satpam yang tidak selalu berada di tempat, sehingga pelanggan merasa kebingungan mendapatkan informasi. Hal itu yang mendorong peneliti untuk melihat ada tidaknya pengaruh servicescape terhadap kepuasan konsumen pada PT. Pegadaian (persero) Cabang Bima.

\section{KAJIAN LITERATUR \\ a. Servicescape}

Servicescape merupakan gaya dan wujud dari lingkungan fisik dan elemenelemen eksperiental lainnya yang ditemukan oleh pelanggan ditempat jasa tersebut disampaikan. (Lovelock \& Wirtz 2011:277). Lovelock \& Wirtz menjelaskan adanya beberapa indikator dari servicescape, yaitu Kondisi lingkungan, Tata ruang, dan Simbol.
b. KepuasanKonsumen
Menurut Tjiptono dan Chandra (2011:292) kata kepuasan (satisfaction) 
berasal dari bahasa latin "satis"artinya cukup, memadai dan "facio"yang artinya melakukan atau membuat. Berdasarkan penjelasan tersebut kepuasan dapat diartikan sebagai "upaya pemenuhan sesuatu" atau "membuat sesuatu memadai". Menurut Hawkins dan Lonney dalam (Tjiptono 2004:101) indikator kepuasan konsumen terdiri dari Kesesuaian harapan, Minat berkunjung kembali, dan Kesediaan Merekomendasi

Dalam penelitian ini, dilakukan untuk melihat bagaimana hubungan serviscape terhadap minat berkunjung kembali konsumen di PT. Pegadaian (Persero) Cabang Bima. Hubungan yang dimaksud adalah hubungan secara parial atauhubungan langsung. Sehingga dapat dibuat kesimpulan apakah ada pengaruh atau tidak.Dari sejumlah hasil penelitian sebelumnya, misalnya penelitian Pratama dan Setyoroni (2015) mejelaskan bahwa Servicescape ikutmemberi pengaruh yang cukup besar bagi puas tidaknya konsumen. Bahkan presenta sekepuasannya mencapai 74,6\%. Sementara sisanya dipengaruhi hal-hal lain.

\section{METODE PENELITIAN}

Penelitian ini dilakukan pada PT. Pegadaian (persero) Cabang Bima. Jumlah populasi dalam penelitian tidak diketahui, sehingga untuk menentukan besar sampel adalah dengan menggunakan rumus Menurut Rao Purba (Sujarweni, 2015:155). Berdasarkan Rao Purba maka jumlah sampel yang digunakan sebesar 96 responden.

Kuisioner yang digunakan terlebih dahulu diuji validitas dan reliabiltas menggunakan Aplikasi SPSS Versi 16. Ada 12 pernyataan yang dibuat, masing-masing variable terdapat 6 pernyataan yang mewakili indikator, yaitu 6 pernyataan tentang Servicescape dan 6 penyataan terkait minat berkunjung ulang. Data diperoleh melalui pembagian kuisioner, wawancara dan observasi. Data yang diperoleh melalui kuisioner dianalisis menggunakan aplikasi SPSS Versi 16. Untuk persamaan regresi, koofisien korelasi dan determinasi secara parsial dan melihat ada tidaknya pengaruh dilihat hubungan secara parsial melalui nilai $t_{\text {hitung }}$.

\section{HASIL DAN PEMBAHASAN}

a. Uji Validitas dan Reliabilitas.

Berikut ini adalah table rekapitulasi nilai rata-rata hasil validitas isntrumen yang dianalisis menggunakan SPSS Versi 20. Adapaun hasildi peroleh adalah sebagai berikut.

Tabel 1.

Nilai Rata-rata Hasil Validitas

Isntrumen dan minat berkunjung

kembali konsumen di PT. Pegadaian (Persero) Cabang Bima.

\begin{tabular}{|c|r|c|c|}
\hline variabel & $\mathbf{r}_{\text {hitung }}$ & rembanding $_{\text {Peterangan }}$ & Keter \\
\hline Servicescape & 0,8 & $\mathbf{0 , 3 0}$ & Valid \\
\cline { 1 - 1 } $\begin{array}{c}\text { Kepuasan } \\
\text { konsumen }\end{array}$ & 0,4 & & Valid \\
\hline
\end{tabular}

Sebelum digunakan untuk mengumpulakn data, setiap pernyataan diuji validitas, dari pernyataan yang dibuat pada variable servicescape semuanya valid. Nilai atau $r_{\text {hirung }}$ terendah penyataanadalah 0,725 dan tertinggi adalah 0,845 sehingga dirataratakana dalah 0,8. Sementara untuk kepuasan konsumen nilai atau $r_{\text {hitung }}$ terendah adalah 0,372 . Artinya lebih dari 0,30 sebagaimana yang disratakan oleh Sugiyono (2016) yaitu 0,30 maka seluruh pernyataan yang disusun adalah valid, karena dikatakan valid jikar ${ }_{\text {hitung }}>r_{\text {tabel }}$.

Selanjutnya, dilakukan uji reliabliitas terhadap instrument tersebut. Adapun hasilnya uji reliabilitas ditunjukkan pada table 2 berikutini.

Tabel 2.

Nilai Rilaibilitas Isntrumen

Servicescape dan Kepuasan Konsumen di

PT. Pegadaian (Persero) Cabang Bima.

\begin{tabular}{|c|c|}
\hline Cronbach's Alpha & N of Items \\
\hline, 854 & 14 \\
\hline
\end{tabular}

Dari table 2 di atas, diperoleh nilai riliabilitas Cronbach's Alpha adalah 0,854. Hal ini berarti bahwa nilai tersebut lebih tinggi dari 0,60 yang menjadi syarat suatu instrument dikatakan reliabilitas (Sugiyono, 2011). Karena nilai Cronbach's Alpha adalah 
$0,854>0,60$ maka instrument tersebut adalah riliabilitas sehingga bisa dilanjutkan untuk pengambilan data.

b. Uji Normalitas

Untuk melihat data tersebut terdistribusi normal atau tidak, digunakan grafik Normal $P-P$ of Regression Standardized Residual. Adapun grafiknya sebagai berikut.

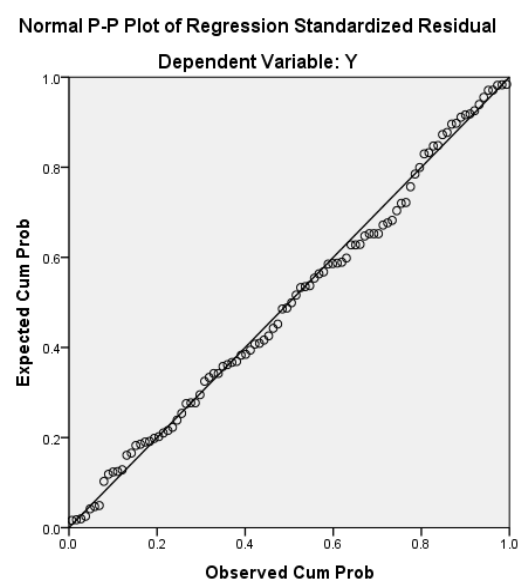

Gambar 1.

GrafikNormal P-P of Regression Standardized Residual

Menunjukkan bahwa grafik Normal P-P of Regression Standardized Residual menggambarkan penyebaran data di sekitar garis diagonal dan penyebarannya mengikuti arah garis diagonal grafik tersebut, maka model regresi yang digunakan dalam penelitian ini memenuhi asumsi normalitas atau datanya terdistrubusi normal.

c. Persamaan regresi Linier, Koerlasi dan Determinasi

Dari hasil analisis menggunakan SPSS Versi 20, maka diperoleh hasil analisis pada table coofficients sebagaimana tabe 3 .

Tabel 3.Table Hasil Analisis SPSS Versi

20 untuk Persamaan Regresi Linier.

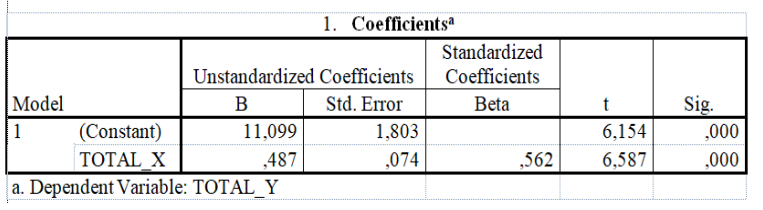

Berdasarkan tabel di atas, maka persamaan regresi linear adalah $\mathrm{Y}=11.099+$ $0,487 X$. han ini berarti bahwa jika Servicescape bernilai 0 (nol) maka kepuasan konsumen bernilai 11.099. dan sebaliknya setiap penambambahan Servicescapei selalu bernilai positif sebesar 0,487 . Hal tersebut berlaku linier.

Sementara untuk melihat bagaimana hubungan dan besar pengaruh keduanya dilihat melalui koofisien koerlasi dan determinasi. Adapun hasil analisisnya adalah sebagai berikut.

Tabel 4

Nilai Koefisien Korelasi dan Determinasi

\begin{tabular}{|l|c|c|cr|}
\multicolumn{9}{|c|}{ Model Summary } \\
Model & $R$ & Square & $\begin{array}{c}\text { Adjusted R } \\
\text { Square }\end{array}$ & $\begin{array}{r}\text { Std. Error of } \\
\text { the Estimate }\end{array}$ \\
\hline 1 &, $562^{\mathrm{a}}$ &, 316 &, 309 & 2,331 \\
\hline a. Predictors: (Constant), Servicescape \\
\hline
\end{tabular}

Dari tabel diatas, diperoleh bahwa hubungan kedua variable yang diteliti adalah diligar pada nilai $R$ yaitu sebesar 0,562 atau hanya sebesar $56,2 \%$ saja. Sementara untu pengaruh servicescape terhadap kepuasan konsumen adalah sebesar 0,316 atau 31,6\%. Sedangkan sisanya sebesar $68,4 \%$ di pengaruhi oleh faktor lain yang tidak termasuk dalam penelitian ini.

\section{d. Uji t.}

Dari hasil analisis yang dilakukan, dan terlihat pada table 4. Bahwa dari hasil analisis menggunakan SPSS Versi 20 tersebut diperolehnilait hitung $=6,154$. Sementara nilai $t_{\text {tabel }}$ adalah sebesar 1,984. Hal ini berarti bahwa $t_{\text {hitung }}>t_{\text {tabel }}$ atau dilihat dari nilai sig maka diperoleh nilai Sig $=0,00$ $<\alpha=0,05$. Hal ini berarti bahwa Servicescape berpengaruh signifikan terhadap Kepuasan Konsumen pada PT. Pegadaian (persero) Cabang Bima.

\section{KESIMPULAN}

Dari hasil penelitian yang dilakukan di PT. Pegadian (Persero) Cabang Bima, diperoleh bahwa Servicescape secara parsial berpengaruh signifikan terhadap Kepuasan Konsumen pada PT. Pegadaian (persero) Cabang Bima. Hal itu juga ditandai dengan korelasi keduanya mencapai 0,562 atau $56,2 \%$ dengan tingkat pengaruhnya mencapai 0,361 atau $31,6 \%$. 


\section{SARAN}

Ada beberapa saran yang sekiranya dapat dilakukan diantaranya adalah;

a. Peneliti selanjutnya dapat mengambangkan lagi penelitian dengan menambah atau melihat variable lain.

b. Mungkin penelitian tidak hanya menggunakan aplikasi statistic saja,

\section{DAFTAR PUSTAKA}

Cynthia Vanessa Djodjobo, Hendra N Tawas. 2014. Pengaruh Orientasi Kewirausahaan, Inovasi Produk, dan Keunggulan Bersaing Terhadap Kinerja Pemasaran Usaha Nasi Kuning di Kota Manado. Jurna IEMBA, Vol.2 No.3, September. Hal. 1214- 1224. ISSN 2303-1174.

Ghozali, I.(2013). Aplikasi Analisis Multiuni variate dengan Program SPSS. Semarang: Badan Universitas Diponegoro.

Hightower, R. Jr, danShariat M. 2009. "Servicescape's Hierarchical Factor Structure Mode". Global Review and Economic Research, Vol. 5 No. 2 Spring: 375-398)

Kotler, P., dan K. L., Keller.(2009). Manajemen Pemasaran Jilid 2, Edisi Ketiga Belas Terjemahan Bob Sabran, MM. Erlangga, Jakarta.

Kotler, P., dan K. L., Keller.(2012). Marketing Management.Edisi 14 Erlangga : Jakarta.

Kotler, P., dan K. L., Keller.(2012). Marketing Management.Edisi 14 Erlangga : Jakarta.

Kotler, P., dan K. L., Keller. 2009. ManajemenPemasaran. Jilid 1, EdisiKetigaBelas, Terjemahan Bob Sabran, MM. Erlangga, Jakarta.

Kotler, Philip and Keller, Kevin Lane. (2012). Marketing Management, 14th Edition.New Jersey: Prentice Hall Published.

Lovelock, Christiopher and JochenWirtz. 2011. Service Marketing People, Technology, Strategy. 7th edition. Upper Saddle River, New Jersey: Pearson Hall.
Pratama, M.P., danSetyoroni. Retno.2015. PengaruhServicescapeterhadapkepua sanKonsumenKAfeRoriGempoldan Kopi AnjisCabangJalanBencanaBengawan Bandung.E-Proceeding of Managemant.Vol.2, No. 1. Pp. 749756

Sugiono, (2010).Metode Penelitian Pendidikan Pendekatan Kuantitatif, kualitatif, dan R\&D ;Bandung: Alfabeta.

Sugiyono 2012.MetodePenelitian Bisnis. (Pendekatan Kuantitatif, Kualitatif dan R\&D) Bandung: CV. Alfabeta

Tjiptono, Fandydan Chandra, Gregorius. 2011. Service, Quality \& Satisfaction. Edisit.

Tjiptono, Fandy. 2004. Manajemen Jasa. Edisi Pertama. Yogyakarta: CV Andi Offset 